\title{
Pengembangan Pembelajaran E-learning Dengan Moodle (Modulator Object-Oriented Dynamic Learning Environment)
}

\author{
M.Samsudin ${ }^{1}$, Ni Nyoman Utami Januhari ${ }^{2}$ \\ Institut Teknologi dan Bisnis (ITB) STIKOM Bali \\ e-mail: 1samsudin@stikom-bali.ac.id, 2amik@ stikom-bali.ac.id
}

Diajukan: 12 Desember 2018; Direvisi: 25 November 2019; Diterima: 25 November 2019

\begin{abstract}
Abstrak
Teknik pembelajaran secara e-learning semakin meningkat di jaman teknologi yang semakin berkembang. Dengan memanfaatkan kemajuan ilmu pengetahuan dan teknologi ini. Pembelajaran secara e-learning sudah diterapkan di lingkungan pendidikan. Dengan pembelajaran e-learning diharapkan dapat memperbaiki pola pembelajaran konvensional menjadi pola pembelajaran digital, seperti yang diharapkan oleh pengelola pendidikan. Masih banyak sekolah yang melakukan pembelajaran secara konvensional sehingga siswa belum dapat secara optimal menerima materi pembelajaran karena keterbatasan waktu pelajaran, sehingga dibutuhkan pengembangan sistem e-learning untuk mempermudah proses pembelajaran siswa. Pengembangan Teknik pembelajaran e-learning yang dikembangkan dengan Moodle. Dalam penelitian ini dibangun system informasi e-learning dengan tampilan Moodle Analisa dan desain sistem dengan pendekatan Zachman Framework dimulai dengan menentukan ruang lingkup sistem (business scope) yang meliputi seluruh data, Activity Diagram, dan Sequence Diagram serta tahap terakhir yang dilakukan adalah membuat technology model yaitu menjelaskan tentang perancangan interface menu dan implementasi e-learning berbasis moodle dengan melakukan kustomisasi pada perangkat lunak Moodle (Modular Object-Oriented Dynamic Learning Environment). Dengan pengembangan e-learning sebagai sarana pembelajaran, kualitas pembelajaran dan hasil belajar semakin mudah dan cepat diterima oleh peserta didik. Selain itu hal ini penulis lakukan demi membantu para anak didik dapat mempelajari dan mengulang kembali materi pelajaran yang telah dipelajari.
\end{abstract}

Kata kunci: Sistem informasi, Pembelajaran, E-learning, Moodle (Modulator Object-Oriented Dynamic Learning Environment), Zachman Framework.

\begin{abstract}
E-learning learning techniques are increasing in the age of increasingly developing technology. By utilizing the advancement of science and technology. E-learning learning has been applied in the educational environment. With e-learning learning is expected to improve conventional learning patterns into digital learning patterns, as expected by education managers. There are still many schools that carry out conventional learning so that students cannot optimally receive learning material because of limited learning time, so the development of e-learning systems is needed to facilitate the learning process of students. Development of e-learning learning techniques developed with Moodle. In this study, an elearning information system with a Moodle display was built. System analysis and design with the Zachman Framework approach begins with determining the scope of the system (business scope) which includes all data, Activity Diagrams and Sequence Diagrams explain about designing menu interfaces and implementing e-learning based on Moodle by customizing the Moodle software (Modular Object-Oriented Dynamic Learning Environment. With the development of e-learning as a learning tool, the quality of learning and learning outcomes is more easily and quickly accepted by students Besides this, the authors do to help students learn and repeat the subject matter that has been learned.
\end{abstract}

Keywords: Information systems, Learning, E-learning, Moodle (Modulator Object-Oriented Dynamic Learning Environment), Zachman Framework.

\section{Pendahuluan}

Teknologi komunikasi dan informasi di dalam dunia Pendidikan adalah suatu usaha yang dilakukan dalam mewujudkan suasana belajar-mengajar yang berbeda agar para peserta didik dapat mengembangkan potensi dirinya. Pendidikan yang di bilang berkualitas adalah dapat menghasilkan siswa- 
siswi yang dapat mengembangkan keterampilan yang bermanfaat bagi dirinya sendiri dan masyarakat. Pembelajaran elektronik (e-Learning) sangat penting diterapkan karena diharapkan dapat memperbaiki pola pembelajaran konvensional menjadi pola pembelajaran digital atau juga di sebutkan konsep pembelajaran yang dilakukan melalui jaringan media elektronik. Model pembelajaran elektronik yang banyak digunakan saat ini adalah Moodle (Modular Object-Oriented Dynamic Learning Environment). Penerapan Teknologi yang sudah masuk ke beberapa pendidikan SMA maupun SMK jika tidak dimanfaatkan dengan baik dan di berdayakan dengan optimal tidak dapat mengubah pola pemikiran dari peserta didik.

Pada satu contoh proses pembelajaran di kelas SMKTI Bali Global Klungkung masih menggunakan konsep manual dengan cara konvensional dengan tatap muka di kelas sesuai pada jam yang telah di tentukan, tanpa adanya tambahan waktu dan materi yang dapat diberikan oleh pengajar. Dalam kegiatan pre-test untuk memberikan kesempatan bagi siswa yang ingin memperbaiki nilai dan mendapatkan nilai tambahan. Penerimaan materi pembelajaran juga kurang optimal dirasakan siswa sehingga dibutuhkan solusi model pembelajaran elektronik (e-learning). Sistem informasi E-Learning berbasis web dengan metode Zachman Framework menggunakan tampilan Moodle, merupakan solusi yang akan dilakukan dalam penelitian ini. Untuk dapat menghasilkan suatu sistem informasi e-Learning. Selain itu, akan dilakukan perancangan user interface serta perancanan e-learning dengan tampilan moodle yang dikembangkan berbasis web menggunakan metode Zachman Framework [1].

Dalam melakukan analisa dan desain sistem dimulai dengan menentukan ruang pendekatan permasalahan yang terjadi serta menentukan ruang lingkup sistem yang meliputi seluruh data, proses dan konfigurasi sistem yang dibutuhkan serta dilanjutkan dengan pembuatan rancangan business model yaitu tata laksana sistem yang dan bentuk Class Diagram, Activity Diagram dan Sequence Diagram [2]. Tahap terakhir yang harus dilakukan adalah membuat technology model yaitu menjelaskan tentang perancangan interface menu, sehingga analisa sistem informasi ini bisa digunakan oleh para programmer untuk melakukan implementasi system dengan pengembangan E-learning berbasis moodle. Kostumisasi pada model akan dilakukan sehingga dapat memenuhi kebutuhan di SMKTI Bali Global Klungkung dengan melakukan kustomisasi pada perangkat lunak Moodle (Modular Object-Oriented Dynamic Learning Environment) [3][4].

\section{Tinjauan Pustaka}

\subsection{State Of The Art Penelitian}

Pembelajaran elektronik dapat digunakan sebagai sarana penunjang proses belajar mengajar, tidak hanya mengimplementasikan materi ajar pada web, tetapi juga menciptakan skenario pembelajaran dengan matang untuk mengundang keterlibatan peserta didik secara aktif dan konstruktif dalam proses belajar mereka. Pada penelitian ini, akan melakukan kustomisasi pada perangkat lunak Moodle (Modular ObjectOriented Dynamic Learning Environment) [5] yang berbasiskan open source untuk diaplikasikan pada portal e-learning. Penelitian ini dilakukan dengan membuat model pembelajaran elektronik (e-Learning) untuk meningkatkan kualitas pembelajaran mata kuliah yang berbasis internet.

Beberapa penelitian sudah pernah dilakukan mengenai teknik pembelajaran secara e-learning, mengenai Penerapan E-learning dalam Inovasi pendidikan. Dalam penelitian ini bagaimana pengaruh perkembangan teknologi dan informasi yang sangat cepat mempengaruhi aspek kehidupan dan bidang pendidikan. Selain itu juga membahas harapan pada system e-learning dimasa yang mendatang yang semakin efektif digunakan dalam metode pembelajaran. Kecenderungan untuk mengembangkan e-learning sebagai salah satu alternatif pembelajaran di lembaga pendidikan dan perbaikan infrastruktur di bidang telekomunikasi informasi yang akan menjadi tantangan bagi dunia pendidikan di Indonesia [6]

Untuk mengembangkan teknologi informasi yang semakin pesat, para siswa membutuhkan waktu yang berkualitas untuk bisa berdiskusi dan membantu pemahaman dalam pembelajaran di kelas, sehingga dibutuhkan salah satu alternatif pembelajaran onlinele-learning. Pada Pengembangan Teknik Pembelajaran dengan Moodle meliputi seluruh data, proses dan konfigurasi sistem yang dibutuhkan serta dilanjutkan dengan pembuatan rancangan business model dan membuat model sistem informasi dan membuat technology model yaitu menjelaskan tentang perancangan interface menu yang bagus dan baik, sehingga dihasilkan interface pengembangan E-Learning yang gampang di mengerti oleh peserta didik. [7]

\subsection{Landasan Teori}

\section{a) Model E-Learning}

Model e-learning untuk membantu pelajar dalam memahami ilmu pengetahuan dapat dilakukan secara konvensional maupun dengan e-Learning. Istilah e-Learning mengandung pengertian yang sangat 
luas, sehingga banyak pakar yang menguraikan tentang definisi e-Learning dari berbagai sudut pandang. Darin E. Hartley yang menyatakan [8]:

Banyak hal yang bisa dilakukan dengan pembelajaran e-learning. Tergantung sekarang peserta didik mampu untuk belajar secara onlinele-learning. Beberapa teori yang bisa dipahami mengenai konsep learning itu bisa di lihat pada Gambar 1.

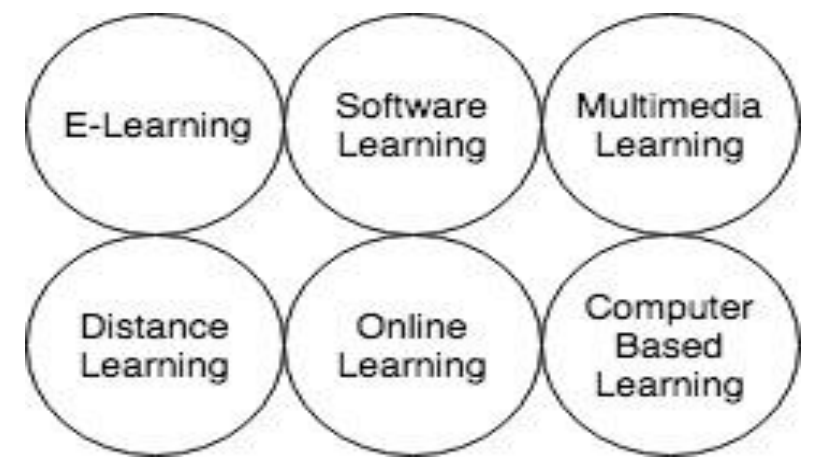

Gambar 1. Teknologi e-learning.

E-Learning merupakan suatu jenis belajar mengajar yang memungkinkan tersampaikannya bahan ajar ke mahasiswa dengan menggunakan media Internet, Intranet atau media jaringan komputer lain. Konsep pembelajaran learning bisa digabungkan dengan yang lainnya tergantung dari kebutuhan yang ingin dilakukan [7].

\section{b) Komponen E-Learning}

Komponen-komponen pembentukan sistem ini yaitu e-learning system, e-learning content, $e$ learning infrastructure (peralatan), e-learning management system, dan Moodle, berikut penjelasannya:

1. e-Learning System

Perangkat lunak yang mem-virtualisasi proses belajar mengajar konvensional. Bagaimana manajemen kelas, pembuatan materi atau konten, forum diskusi, system penilaian (rapor), sistem ujian online dan segala fitur yang berhubungan dengan manajemen proses belajar mengajar. Sistem perangkat lunak tersebut sering disebut dengan Learning Management System (LMS).

2. e-Learning Content (Isi)

Konten dan bahan ajar yang ada pada e-Learning system (Learning Management System). Konten dan bahan ajar ini bisa dalam bentuk Multimedia-Based Content (konten berbentuk multimedia interaktif) atau Text-based Content (konten berbentuk teks seperti pada buku pelajaran biasa) .

3. E-Learning Infrastructure (Peralatan)

Infrastruktur e-Learning dapat berupa personal computer (PC), jaringan komputer dan perlengkapan multimedia. Termasuk di dalamnya peralatan teleconference apabila kita memberikan layanan synchronous learning melalui teleconference.

4. Learning management system

Dalam proses penyelenggaraan e-Learning, maka dibutuhkan sebuah Learning Management System (LMS), yang berfungsi untuk mengatur tata laksana penyelenggaraan pembelajaran di dalam model e-Learning. Sering juga LMS dikenal sebagai CMS (Course Management System), [9] umunya CMS dibangun berbasis web, yang akan berjalan pada sebuah web server dan dapat diakses oleh pesertanya melalui web browser (web client). Server biasanya ditempatkan di universitas atau lembaga lainnya, yang dapat diakses dari manapun oleh pesertanya, dengan memanfaatkan koneksi internet.

Pada umumnya, secara dasar CMS memberikan sebuah tool bagi instruktur, educator atau pendidik untuk membuat website pendidikan dan mengatur akses kontrol, sehingga hanya peserta yang terdaftar yang dapat mengakses dan melihatnya. Selain menyediakan pengontrolan, CMS juga menyediakan berbagai tools yang menjadikan pembelajaran lebih efektif dan efisien, seperti menyediakan layanan untuk mempermudah upload dan share material pengejaran, diskusi online, chatting, penyelenggaraan kuis, survey, laporan (report) dan sebagainya. 
5. Pengertian Moodle

Moodle merupakan sebuah CMS berbasis open source yang saat ini digunakan oleh universitas, lembaga pendidikan, K-12 School, bisnis dan instruktur individual yang ingin menggunakan teknologi web untuk pengelolaan kursusnya. Moodle saat ini dipakai oleh lebih dari 2000 organisasi pendidikan di seluruh dunia untuk mengirimkan online courses dan sebagai perangkat tambahan (supplement) bagi traditional face-to-face courses [9].

Moodle adalah suatu course content management (CMS), yang diperkenalkan pertama kali oleh Martin Dougiamas, seorang computer scientist dan educator, yang menghabiskan sebagian waktunya untuk mengembangkan sebuah learning management system di salah satu perguruan tinggi di kota Perth, Australia [10].

6. Metode Zachman Framework

Zachman Framework menggambarkan arsitektur organisasi secara umum dan menguraikannya sebagai enterprise sistem yang kompleks. Zachman Framework merupakan salah satu kerangka kerja yang populer dalam memetakan arsitektur informasi di sebuah organisasi di mana kerangka kerja ini dapat menyediakan cara untuk memandang dan mendefinisikan elemen-elemen dari suatu enterprise secara formal dan terstruktur dengan baik. Dengan merancang sistem sesuai dengan kerangka kerja ini, maka developer dapat merancang desain yang bersih, mudah dimengerti, seimbang, dan lengkap [11][12].

Tujuan dari kerangka kerja ini adalah untuk menyediakan struktur dasar yang mendukung organisasi, akses, integrasi, interpretasi, pengembangan, manajemen, dan satu set representasi arsitektur sistem informasi organisasi [13][14].

\section{Metode Penelitian}

\subsection{Model Konseptual Penelitian}

Penelitian ini menggunakan pendekatan kerangka arsitektur informasi Zachman Framework, sehingga metode penelitiannya juga mengikuti kerangka dari Zachman Framework tersebut yang tampak seperti gambar berikut [7]: Berdasarkan kerangka arsitektur, tahap pertama yang harus dilakukan adalah mendefinisikan permasalahan yang ada, kemudian melakukan analisa dan desain menggunakan pendekatan Zachman Framework yang dimulai dengan menentukan ruang lingkup sistem (business scope) yang meliputi seluruh data, proses dan konfigurasi sistem yang dibutuhkan serta dilanjutkan dengan pembuatan rancangan business model yaitu tata laksana sistem yang digambarkan dengan Use Case Diagram dan membuat model sistem informasi (information system model) dalam bentuk Class Diagram, Activity Diagram dan Sequence Diagram. Tahap yang harus dilakukan adalah membuat technology model yaitu menjelaskan tentang perancangan interface menu, kotak dialog, dan formulir yang digunakan. Tahap terakhir adalah dengan melakukan implementasi sistem informasi E-Learning dengan kustomisasi pada perangkat lunak Moodle (Modular Object-Oriented Dynamic Learning Environment). [7]

\section{Hasil Analisis Data dan Pembahasan}

\subsection{Analisa Kebutuhan Sistem dan Data}

Analisa kebutuhan sistem merupakan tahapan penting dalam membangun system informasi, karena berkaitan dengan kebutuhan sistem secara keseluruhan, maka kegagalan memenuhi kebutuhan jenis ini berakibat pada sistem secara keseluruhan.

Analisa kebutuhan data digunakan untuk mengetahui kelengkapan data yang dibutuhkan pada saat implementasi Learning Management System (LMS) menggunakan Moodle. Berikut adalah kelengkapan data yang dibutuhkan pada saat implementasi: [7]

Tabel 1. Analisa Kebutuhan Data

\begin{tabular}{cllll}
\hline No & Nama Proses & \multicolumn{1}{c}{ Deskripsi Proses } & Data Input & Aktor / User \\
\hline 1 & Login & $\begin{array}{l}\text { Authentifikasi user atau pengguna yang akan } \\
\text { masuk ke system e-Learning }\end{array}$ & Username, Password & $\begin{array}{l}\text { Siswa, Guru, dan } \\
\text { Admin }\end{array}$ \\
\hline 2 & Registrasi & Digunakan untuk mendaftarkan pengguna & Guru, Siswa & Siswa, guru \\
\hline 3 & $\begin{array}{l}\text { Pengelolaan data } \\
\text { Mata pelajaran }\end{array}$ & $\begin{array}{l}\text { Digunakan untuk mengelola data mata pelajaran } \\
\text { berupa penambahan, penghapusan dan perubahan } \\
\text { data mata pelajaran }\end{array}$ & Mata kuliah & Admin \\
\hline 4 & Upload Materi & $\begin{array}{l}\text { Digunakan untuk mengunggah materi ke dalam } \\
\text { system e-Learning }\end{array}$ & Materi, Mata pelajaran & Guru \\
\hline 5 & Download Materi & $\begin{array}{l}\text { Digunakan untuk mengunduh materi yang } \\
\text { tersedia atau yang disediakan oleh guru }\end{array}$ & Materi, Mata pelajaran & Siswa \\
\hline
\end{tabular}

JURNAL SISTEM DAN INFORMATIKA Vol. 14, No. 1, November 2019. 


\begin{tabular}{cllll}
\hline No & Nama Proses & \multicolumn{1}{c}{ Deskripsi Proses } & Data Input & Aktor / User \\
\hline 6 & Upload Tugas & Digunakan untuk mengunduh tugas & Materi, mata pelajaran & Siswa \\
\hline 7 & Lihat Nilai & Proses untuk melihat nilai & Nilai & Siswa \\
\hline
\end{tabular}

\subsection{Konfigurasi Jaringan Komputer}

Implementasi perangkat lunak e-Learning menggunakan Moodle akan dikembangkan secara online dengan perangkat web server yang mempunyai alamat domain dan ip public. Sehingga para pengguna dapat mengakses system e-learning melalui jaringan internet. Konfigurasi jaringan komputer pada implemntasi perangkat lunak e-learning menggunakan moodle terlihat seperti gambar berikut: [7]

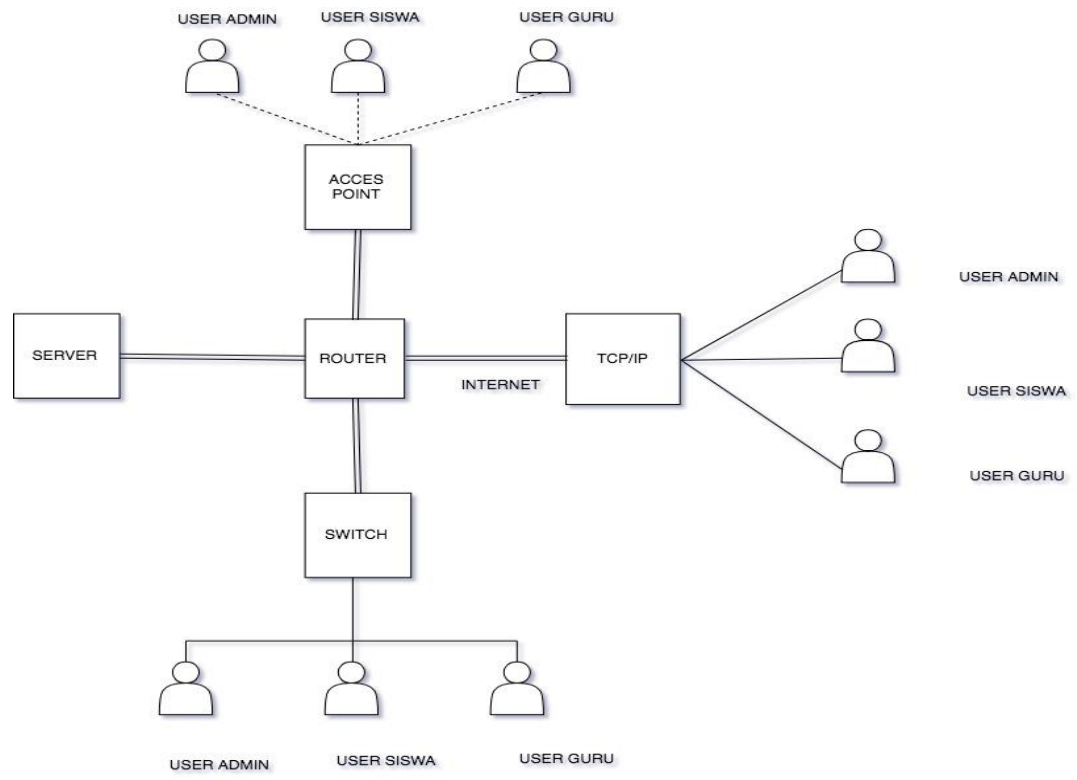

Gambar 2. Konfigurasi jaringan.

\subsection{Moodle Proses}

Moodle Proses E-Learning adalah model merepresentasikan sebuah realitas dalam dunia nyata. Moodle proses global merupakan salah satu cara untuk menstrukturkan permasalahan-permasalahan yang menunjukkan kebutuhan dokumen bisnis atau perancangan teknik. Model logikal (conceptual model atau business model) dapat digunakan untuk menunjukkan tentang "apa" mengenai sistem yang dimodelkan dan diimplementasikan secara "independen" terhadap implementasi tekniknya. Model logikal merupakan sebuah teknik untuk mengorganisasikan dan mendokumentasikan struktur dan aliran data melewati sebuah "proses" dalam sistem dan/atau logika kebijakan atau prosedur yang akan diimplementasikan dengan "proses" dalam sistem. Moodle logikal ditunjukkan dengan diagram aliran data $(D A D)$ yang berupa $D A D$ global (context diagram) dan DAD level yang lebih rendah (Leveled DAD).

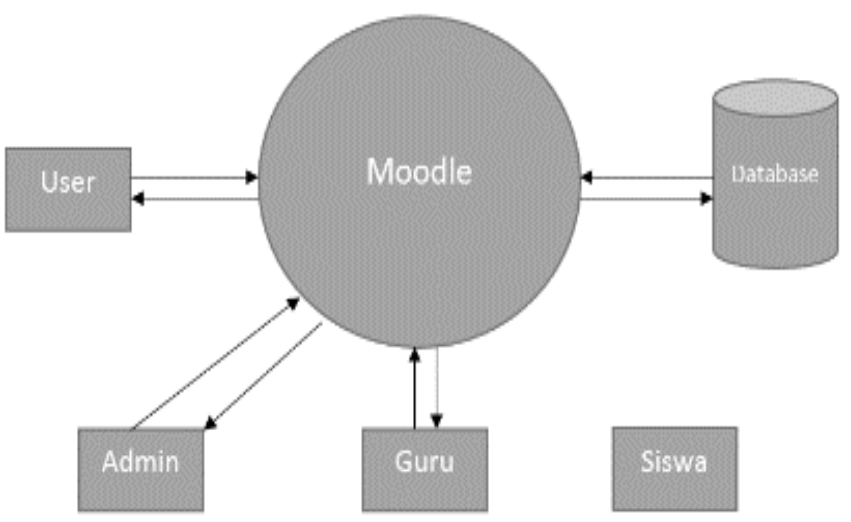

Gambar 3. Moodle proses 


\subsection{Use Case Diagram}

Use case diagram menggambarkan apa yang dilakukan oleh sistem dan tidak menggambarkan bagaimana sistem melakukannya. Komponen use case diagram terdiri dari : Actor, use case dan relation. Aktor menggambarkan orang, system atau external entitas/ stakeholder yang menyediakan atau menerima informasi dari sistem, sedangkan use case adalah apa yang dimainkan/dilakukannya dengan relation sebagai penunjuknya [7].

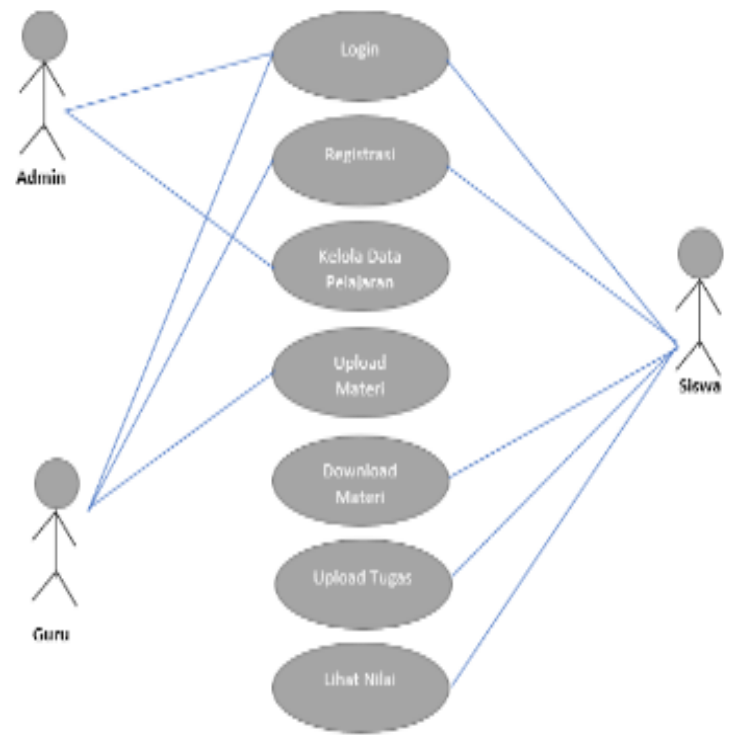

Gambar 4. Use case diagram.

\subsection{Class Diagram}

Class diagram yang digunakan pada teknik pembelajaran e-learning [7].

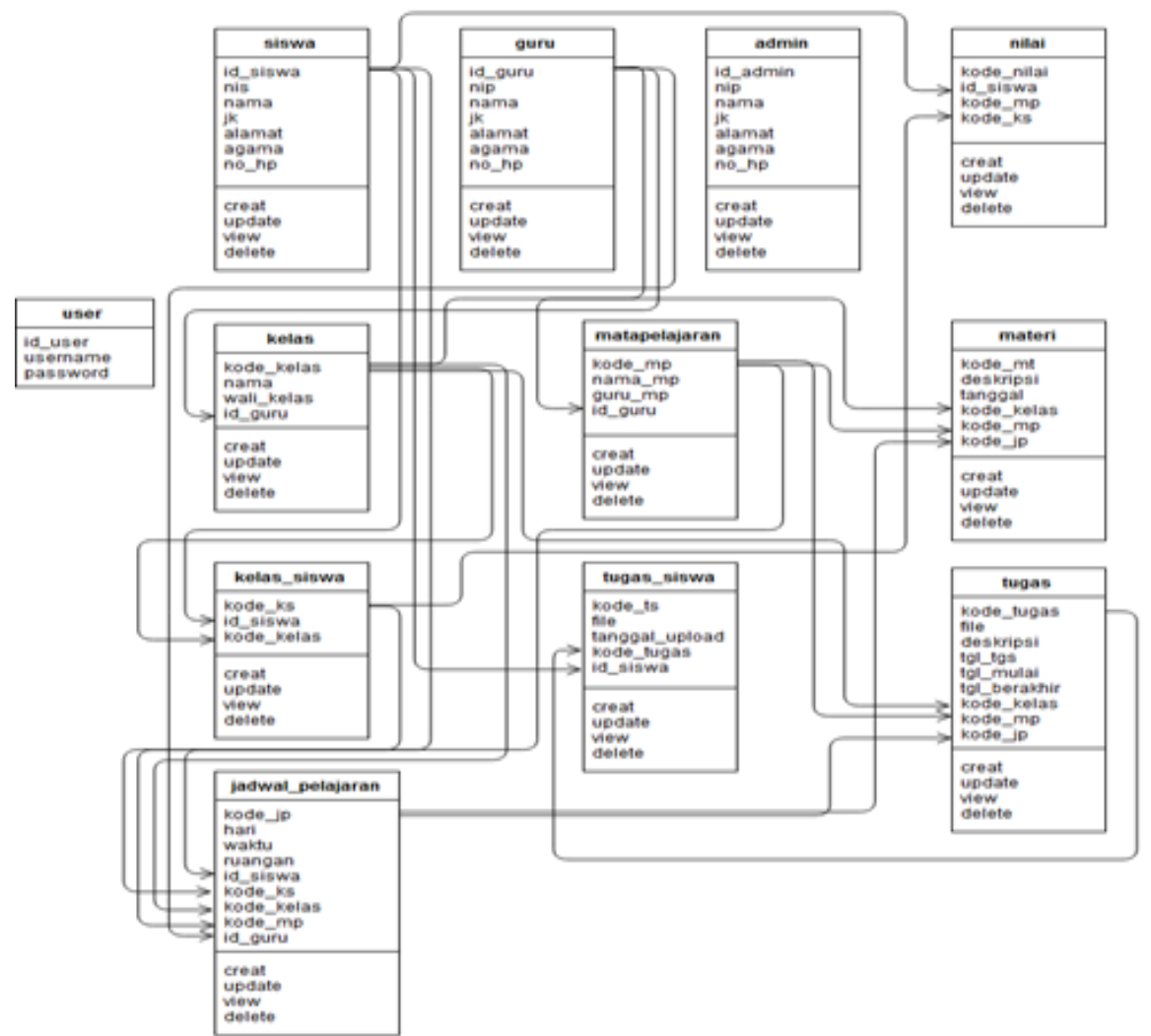

Gambar 5. Class diagram sistem. 
4.6. Interface system

Interface system e-learning yang di terapkan di SMK TI Global Klungkung: [7]

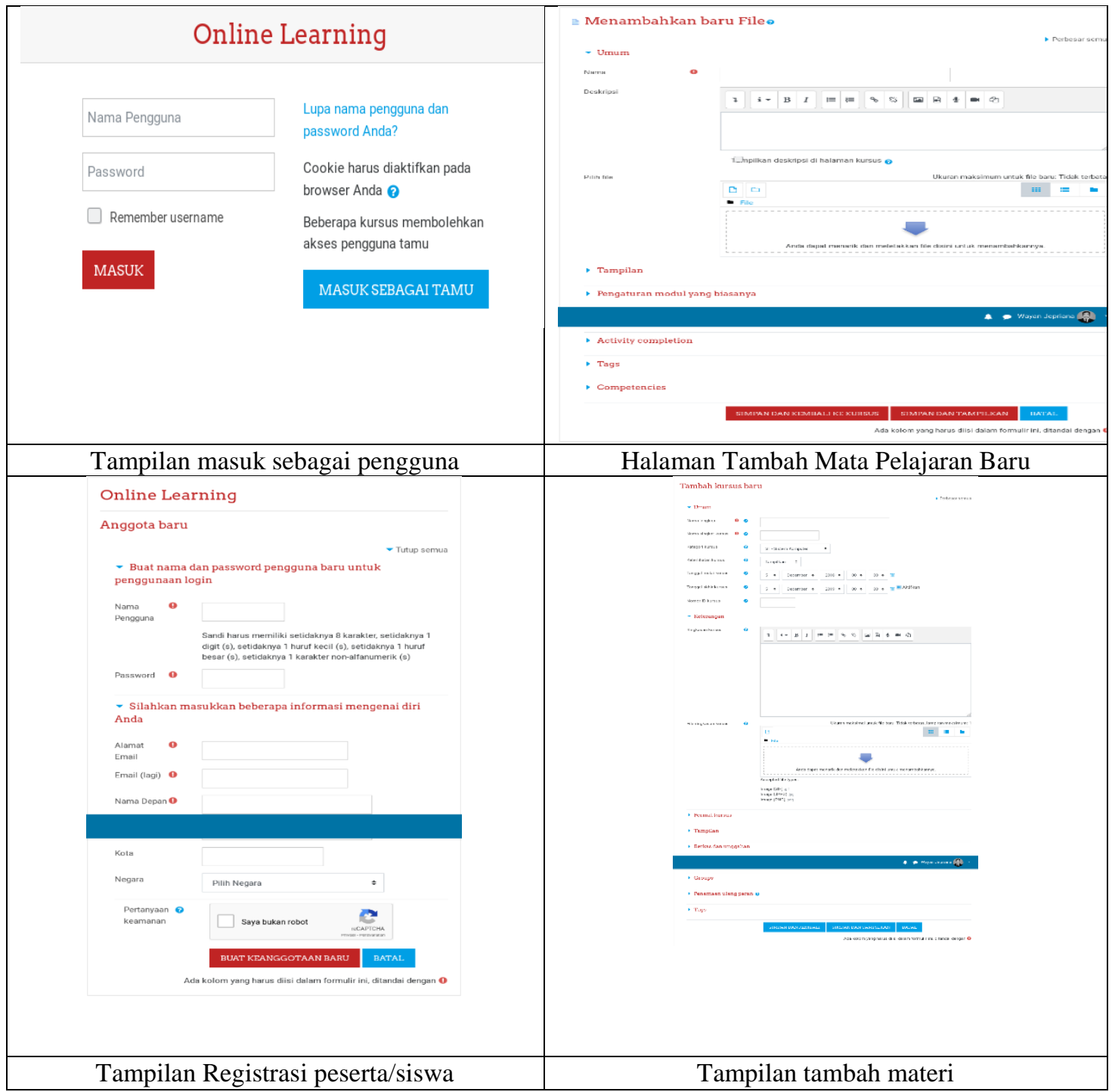

Gambar 6. Tampilan Sistem onlinele-learning.

\section{Kesimpulan}

Berdasarkan hasil penelitian dari permasalahan yang terjadi hasil analisis dan pembahasan yang diperoleh, maka dapat disimpulkan bahwa efektivitas penggunaan media pembelajaran e-learning lebih tinggi dari pada menggunakan media pembelajaran konvensional. E-learning merupakan salah satu alternatif media pembelajaran interaktif yang mengembangkan sikap aktif, mandiri dan kreatif. Pengembangan E-learning dilakukan dengan kustomisasi pada perangkat lunak Moodle (Modular ObjectOriented Dynamic Learning Environment) yang berbasiskan open source untuk diaplikasikan pada $e$ learning SMKTI Bali Global Klungkung.

\section{Daftar Pustaka}

[1] Z. Yang, Z. Feng, L. Song, and S. Guo, "Actualizing of Information Management Systems for Special Vehicles Enterprise using Zachman Framework,” pp. 760-764, 2008.

[2] "Semantic Web Processes: Semantics Enabled Annotation, Discovery , Composition and Orchestration of," p. 7695, 2003.

[3] A. M. Elkhadir and I. O. Saeed, "Job Satisfaction of Radiographic Technologist in Sudan and the Main Reasons of Dissatisfaction," vol. 7, no. 1, pp. 2016-2018, 2018. 
[4] U. Narasimhamurthy and K. Al Shawkani, "Teaching of Programming Languages : An Introduction to Dynamic Learning Objects," pp. 114-115, 2009.

[5] M. A. S. Kamal, J. Murata, and K. Hirasawa, "Task-Oriented Reinforcement Learning for Continuous Tasks in Dynamic Environment Mw."

[6] M. Data, P. Jauh, and D. I. Kota, "Penyusunan sistem informasi ruang publik berbasis."

[7] M. Samsudin, “ANALISA PENGEMBANGAN E-LEARNING,” no. Selisik, 2018.

[8] D. T. Juniper, R. H. Phipps, and G. Bertin, "Effect of dietary supplementation with seleniumenriched yeast or sodium selenite on selenium tissue distribution and meat quality in beef cattle," no. July, 2008.

[9] A. Prof, A. Adamov, S. Mehdiyev, and E. Seyidzade, "Good Practice of Data Modeling and Database Design for UMIS . Course Registration System Implementation,” 2002.

[10] Y. Lin, "Research on Computer network Course in Information Management and Information System V4-176," pp. 175-177, 2010.

[11] R. Varga, "Zachman Framework in Teaching Information Systems," 2003.

[12] G. Piho, "Domain Analysis with Archetype Patterns Based Zachman Framework for Enterprise Architecture," pp. 1351-1356.

[13] Z. Chen and R. Pooley, "Rediscovering Zachman Framework using Ontology from a Requirement Engineering Perspective," pp. 3-8, 2009.

[14] M. Nikolaidou and N. Alexopoulou, "Enterprise Information System Engineering: A Model-based Approach based on the Zachman Framework," pp. 1-10, 2008. 